\title{
Upaya meningkatkan kompetensi guru dalam menyusun rencana pelaksanaan pembelajaran melalui workshop dan bimbingan berkelanjutan
}

\author{
Yulinasmawati Yulinasmawati ${ }^{*}$ \\ Sekolah Dasar Negeri 16 Lubuk Begalung, Pesisir Selatan
}

\begin{tabular}{l} 
Article Info \\
\hline Article history: \\
Received April $18^{\text {th }}, 2021$ \\
Revised May $20^{\text {th }}, 2021$ \\
Accepted Jun $26^{\text {th }}, 2021$ \\
\hline
\end{tabular}

\section{Keyword:}

RPP

Workshop

Bimbingan berkelanjutan

\begin{abstract}
Penelitian Tindakan Sekolah dilaksanakan di UPT SDN 16 Lubuk Begalung Kecamatan Lengayang. Kabupaten Pesisir Selatan yang merupakan sekolah binaan peneliti sebagai kepala sekolah, terdiri atas dua puluh guru kelas dan guru mata pelajaran sebagai sampel, dan dilaksanakan dalam dua siklus. $\mathrm{Ke}$ dua puluh orang guru tersebut menunjukkan sikap yang baik dan termotivasi dalam menyusun RPP dengan lengkap. Hal ini peneliti ketahui dari hasil pengamatan pada saat melakukan wawancara dan bimbingan penyusunan RPP. Pada siklus pertama semua guru (dua puluh orang) mencantumkan penilaian hasil belajar dalam RPP-nya meskipun sub-sub komponennya (teknik, bentuk instrumen, soal), pedoman penskoran, dan kunci jawabannya kurang lengkap. Jika dipersentasekan, $45 \%$. tiga orang guru masing-masing mendapat skor 1 dan tiga guru masing-masing mendapat skor 2 (cukup baik), lima orang mendapat skor 3 (baik), dan tiga orang mendapat skor 4 (sangat baik). Pada siklus kedua kedua puluh guru tersebut mencantumkan penilaian hasil belajar dalam RPP-nya meskipun ada guru yang masih keliru dalam menentukan teknik dan bentuk penilaiannya. Tiga orang mendapat skor 2(cukup baik), Tujuh orang mendapat skor 3 (baik) dan empat orang mendapat skor 4 (sangat baik). Jika dipersentasekan, 55\%, terjadi peningkatan 10\% dari siklus I. Berdasarkan pembahasan di atas terjadi peningkatan kompetensi guru dalam menyusun RPP. Pada siklus I nilai rata-rata komponen RPP 71\%, pada siklus II nilai rata-rata komponen RPP 91\%, terjadi peningkatan $20 \%$.
\end{abstract}

(C) 2021 The Authors. Published by IICET.

This is an open access article under the CC BY-NC-SA license (https://creativecommons.org/licenses/by-nc-sa/4.0

\section{Corresponding Author:}

Yulinasmawati Yulinasmawati,

Sekolah Dasar Negeri 16 Lubuk Begalung, Pesisir Selatan

Email: yulinasmawati@gmail.com

\section{Pendahuluan}

Materi mencari keliling bangun datar sederhana merupakan salah satu kompetensi dasar yang harus dikuasai siswa SD khususnya di kelas III. Untuk itu, menurut Sri (2006:127) "Konsep mencari keliling suatu bangun geometri dapat ditanamkan kepada siswa SD melalui kegiatan siswa." Hal ini dilakukan untuk mencegah siswa memahami konsep keliling secara verbal atau hannya dengan menghafal rumus mencari keliling.

Salah satu fakta yang ditemui ketika guru meminta siswa mencari keliling persegi panjang, yang diketahui panjang $6 \mathrm{~cm}$ dan lebar $4 \mathrm{~cm}$, dan jawaban yang diberikan salah seorang siswa adalah $24 \mathrm{~cm}$ karena $6 \mathrm{~cm} \times 4$ $\mathrm{cm}$. Melihat hal ini, jelaslah bahwa masih ada siswa yang belum dapat membedakan konsep keliling persegi 
panjang dengan konsep luas persegi panjang. Padahal, dari keterangan guru, materi ini telah diajarkan sebelumnya dan jawaban yang seharusnya diberikan siswa adalah $20 \mathrm{~cm}$ karena rumus keliling persegi panjang $2 \mathrm{p}+21=2 \times 6 \mathrm{~cm}+2 \times 4 \mathrm{~cm}=20 \mathrm{~cm}$.

Dalam pelaksanaan strategi belajar kooperatif tipe STAD banyak terdapat manfaat, baik bagi siswa yang cepat memahami materi pelajaran maupun bagi siswa yang lambat memahami materi pelajaran. Bagi siswa yang cepat memahami materi pelajaran dapat meningkatkan kepercayaan diri dan tanggung jawab untuk membimbing teman-temanya dalam menguasai materi pelajaran karena nilai kelompok bergantung pada nilai rata-rata masing-masing anggota kelompok. Sedangkan bagi siswa yang lambat menguasai materi pelajaran, dapat belajar dari teman satu kelompok yang terlebih dahulu memahami materi pelajaran karena belajar dari dari teman sebaya cenderung lebih cepat dimengerti siswa dibanding belajar dari orang dewasa seperti guru.

Dengan melihat banyak manfaat dari pelaksanaan strategi belajar kooperatif tife STAD, diperkirakan strategi belajar ini dapat dilaksanakan, apalagi strategi belajar kooperatif tipe STAD ini adalah strategi yang paling sederhana bila dibanding strategi belajar kooperatif jenis lain. Apalagi bagi guru yang baru belajar melaksanakan strategi belajar kooperatif. Berdasarkan uraian yang telah dijabarkan sebelumnya, maka penulis berkeinginan melaksanakan penelitian tindakan kelas (PTK) dengan judul "Peningkatan Hasil Belajar Keliling Bangun Datar Melalaui Strategi Belajar Kooperatif Tipe STAD di Kelas III UPT SDN 04 Lunang Kec. Lunang Kabupaten Pesisir Selatan"

\section{Metode}

Penelitian ini berbentuk Penelitian Tindakan Sekolah (School Action Research), yaitu sebuah penelitian yang merupakan kerjasama antara peneliti dan guru, dalam meningkatkan kemampuan guru agar menjadi lebih baik dalam menyusun rencana pelaksanaan pembelajaran.

Metode yang digunakan dalam penelitian ini adalah metode deskriptif, dengan menggunakan teknik persentase untuk melihat peningkatan yang terjadi dari siklus ke siklus. "Metode deskriptif dapat diartikan sebagai prosedur pemecahan masalah yang diselidiki dengan menggambarkan/melukiskan keadaan subjek/objek penelitian (seseorang, lembaga, masyarakat, dan lain-lain) pada saat sekarang berdasarkan faktafakta yang tampak atau sebagaimana adanya (Nawawi, 1985:63). Dengan metode ini peneliti berupaya menjelaskan data yang peneliti kumpulkan melalui komunikasi langsung atau wawancara, observasi/pengamatan, dan diskusi yang berupa persentase atau angka-angka.

Penelitian ini bertujuan untuk mendeskripsikan kesulitan-kesulitan yang dialami oleh guru dalam menyusun RPP. Selanjutnya peneliti memberikan alternatif atau usaha guna meningkatkan kemampuan guru dalam membuat rencana pelaksanaan pembelajaran. Penelitian ini dilakukan di UPT SDN 16 Lubuk Begalung Kecamatan Lengayang. PTS ini dilaksanakan pada semester satu tahun 2020 selama kurang lebih dua bulan mulai Agustus sampai dengan Oktober 2020.

Tabel <Jadwal Pelaksanaan Penelitian>

\begin{tabular}{lc}
\hline Kegiatan & Waktu \\
Membuat proposal & 8 s.d. 10 Agustus 2020 \\
Merevisi proposal & 12 s.d. 13 Agustus 2020 \\
Melaksanakan PTS & 30 Agustus s.d. 25 September 2020 \\
Membuat laporan PTS & 1 Oktober s.d. 6 Oktober 2020 \\
Mempresentasikan hasil PTS & 10 s.d. 15 Oktober 2020 \\
\hline
\end{tabular}

Rencana pelaksanaan dilakukan dalam dua siklus yaitu: Siklus I dan Siklus II. Peneliti mengharapkan secara rinci indikator pencapaian hasil paling rendah $80 \%$ guru membuat kesebelas komponen Rencana Pelaksanaan Pembelajaran, yaitu (1) Komponen identitas mata pelajaran diharapkan ketercapaiannya $100 \%$. (2) Komponen standar kompetensi diharapkan ketercapaiannya 100\%. (3) Komponen kompetensi dasar diharapkan ketercapaiannya 100\%. (4) Komponen indikator pencapaian kompetensi diharapkan ketercapaiannya 80\%. (5) Komponen tujuan pembelajaran diharapkan ketercapaiannya 75\%. (6) Komponen materi pembelajaran diharapkan kecercapaian 100\%. (7) Komponen alokasi waktu diharapkan ketercapaiannya 100\%. (8) Komponen metode pembelajaran diharapkan kecercapaiannya 75\%. (9) Komponen langkah-langkah kegiatan pembelajaran diharapkan ketercapaiannya 75\%. (10) Komponen sumber belajar diharapkan ketercapaiannya 75\%. (11) Komponen penilaian (soal, pedoman penskoran, kunci jawaban) diharapkan ketercapaiannya $75 \%$. 


\section{Hasil dan Pembahasan}

\section{Deskripsi Hasil Penelitian}

Berdasarkan hasil observasi peneliti terhadap lima RPP yang dibuat guru (khusus pada siklus I), diperoleh informasi/data bahwa masih ada guru yang tidak melengkapi RPP-nya dengan komponen dan subsubkomponen RPP tertentu, misalnya komponen indikator dan penilaian hasil belajar (pedoman penskoran dan kunci jawaban). Rumusan kegiatan siswa pada komponen langkah-langkah kegiatan pembelajaran masih kurang tajam, interaktif, inspiratif, menantang, dan sistematis.

Dilihat dari segi kompetensi guru, terjadi peningkatan dalam menyusun Rencana Pelaksanaan Pembelajaran dari siklus ke siklus . Hal itu dapat dilihat pada lampiran Rekapitulasi Hasil Penyusunan RPP dari Siklus ke Siklus (Lampiran 4).

\section{Siklus I (Pertama)}

Siklus pertama terdiri dari empat tahap yakni: (1) perencanaan, (2) pelaksanaan, (3) observasi, dan (4) refleksi seperti berikut ini.

1. Perencanaan ( Planning ). Adapun proses yang termasuk pada tahap ini adalah membuat lembar wawancara, membuat format/instrumen penilaian RPP, membuat format rekapitulasi hasil penyusunan RPP siklus I dan II, dan membuat format rekapitulasi hasil penyusunan RPP dari siklus ke siklus.

\section{Pelaksanaan (Acting)}

Pada saat awal siklus pertama indikator pencapaian hasil dari setiap komponen RPP belum sesuai/tercapai seperti rencana/keinginan peneliti. Hal itu dibuktikan dengan masih adanya komponen RPP yang belum dibuat secara lengkap oleh guru. Sebelas komponen RPP yakni: 1) identitas mata pelajaran, 2) standar kompetensi, 3) kompetensi dasar, 4) indikator pencapaian kompetensi, 5) tujuan pembelajaran, 6) materi ajar, 7) alokasi waktu, 8) metode pembelajaran, 9) langkah-langkah kegiatan pembelajaran, 10) sumber belajar, 11) penilaiaan hasil belajar ( soal, pedoman penskoran, dan kunci jawaban). Hasil observasi pada siklus kesatu dapat dideskripsikan berikut ini:

Observasi dilaksanakan, 30 Agustus s.d 3 september 2020, terhadap Dua Puluh orang guru. Semuanya menyusun RPP, tapi masih ada guru yang belum melengkapi RPP-nya baik dengan komponen maupun subsub komponen RPP tertentu. Satu orang tidak melengkapi RPP-nya dengan komponen indikator pencapaian kompetensi. Komponen hasil belajar adalah dua orang tidak melengkapinya dengan teknik dan bentuk instrumen, empat orang tidak melengkapinya dengan teknik, bentuk instumen, soal, pedoman penskoran, dan kunci jawaban, dua orang tidak melengkapinya dengan teknik, pedoman penskoran, dan kunci jawaban, tiga orang tidak melengkapinya dengan soal, pedoman penskoran, dan kunci jawaban, dan satu orang tidak melengkapinya dengan pedoman penskoran dan kunci jawaban. Selanjutnya mereka dibimbing dan disarankan untuk melengkapinya.

\section{Siklus II (Kedua)}

Siklus kedua juga terdiri dari empat tahap yakni: (1) perencanaan, (2) pelaksanaan, (3) observasi, dan (4) refleksi. Hasil observasi pada siklus kedua dapat dideskripsikan dengan observasi dilaksanakan 27-30 September 2020, terhadap lima belas orang guru. Semuanya menyusun RPP, tapi masih ada guru yang keliru dalam menentukan kegiatan siswa dalam langkah-langkah kegiatan pembelajaran dan metode pembelajaran, serta tidak memilah/ menguraikan materi pembelajaran dalam sub-sub materi. Komponen penilaian hasil belajar, yaitu tujuh orang keliru dalam menentukan teknik dan bentuk instrumennya, tiga orang keliru dalam menentukan bentuk instrumen berdasarkan teknik penilaian yang dipilih, empat orang kurang jelas dalam menentukan pedoman penskoran, satu orang tidak menuliskan rumus perolehan nilai siswa dan selanjutnya mereka dibimbing dan disarankan untuk melengkapinya.

\section{Pembahasan}

Penelitian Tindakan Sekolah dilaksanakan di UPT SDN 16 Lubuk Begalung Kecamatan Lengayang. Kabupaten Pesisir Selatan yang merupakan sekolah binaan peneliti sebagai kepala sekolah, terdiri atas dua puluh guru kelas dan guru mata pelajaran sebagai sampel, dan dilaksanakan dalam dua siklus. Ke dua puluh orang guru tersebut menunjukkan sikap yang baik dan termotivasi dalam menyusun RPP dengan lengkap. Hal ini peneliti ketahui dari hasil pengamatan pada saat melakukan wawancara dan bimbingan penyusunan RPP. 
Selanjutnya dilihat dari kompetensi guru dalam menyusun RPP, terjadi peningkatan dari siklus ke siklus.

1. Komponen Identitas Mata Pelajaran

Pada siklus pertama semua guru (dua puluh orang guru) mencantumkan identitas mata pelajaran dalam RPP-nya (melengkapi RPP-nya dengan identitas mata pelajaran). Jika dipersentasekan, 84\%. Dua belas orang guru mendapat skor 3 (baik) dan dua orang mendapat skor 4 (sangat baik). Pada siklus kedua dua puluh guru tersebut mencantumkan identitas mata pelajaran dalam RPP-nya. Semuanya mendapat skor 4 (sangat baik). Jika dipersentasekan, 100\%, terjadi peningkatan 16\% dari siklus I.

\section{Komponen Standar Kompetensi}

Pada siklus pertama semua guru (dua puluh orang) mencantumkan standar kompetensi dalam RPP-nya (melengkapi RPP-nya dengan standar kompetensi), jika di persentasekan 100\%. Pada siklus kedua kedua puluh orang guru tersebut mencantumkan standar kompetensi dalam RPP-nya jika di persentasekan, 100\%. Baik pada siklus 1 atau siklus dua seluruh guru telah mencantumkan standar kompetensi.

\section{Komponen Kompetensi Dasar}

Pada siklus pertama semua guru (dua puluh orang) mencantumkan kompetensi dasar dalam RPP-nya (melengkapi RPP-nya dengan kompetensi dasar). Jika dipersentasekan, 81\%. Satu orang guru mendapat skor 1 (kurang baik), dua orang guru masing-masing mendapat skor 2 (cukup baik), dan dua orang guru masing-masing mendapat skor 3 (baik). Delapan guru mendapat skor 4 (sangat baik). Pada siklus kedua kedua puluh orang guru tersebut mencantumkan kompetensi dasar dalam RPP-nya. Dua mendapat skor 3 (baik) dan sebelas orang mendapat skor 4 (sangat baik). Jika dipersentasekan, 93\%, terjadi peningkatan $12 \%$ dari siklus I.

4. Komponen Indikator Pencapaian Kompetensi

Pada siklus pertama dua puluh orang guru mencantumkan indikator pencapaian kompetensi dalam RPPnya (melengkapi RPP-nya dengan indikator pencapaian kompetensi). Jika dipersentasekan, 86\%. Dua orang guru masing-masing mendapat skor 1 dan 2 (kurang baik dan cukup baik). Delapan orang guru mendapat skor 3 (baik). Dua orang guru mendapat skor 4 (sangat baik).Pada siklus kedua 2 guru tersebut mencantumkan indikator pencapaian kompetensi dalam RPP-nya. Enam orang mendapat skor 3 (baik) dan enam orang mendapat skor 4 (sangat baik). Jika dipersentasekan, 93\%, terjadi peningkatan 7\% dari siklus I.

5. Komponen Tujuan Pembelajaran

Pada siklus pertama semua guru (dua puluh orang) mencantumkan tujuan pembelajaran dalam RPP-nya (melengkapi RPP-nya dengan tujuan pembelajaran). Jika dipersentasekan, 55\%. tiga orang guru mendapat skor 1 (kurang baik), dua orang mendapat skor 2 (cukup baik), dan tiga orang mendapat skor 3 (baik) dan enam orang guru mendapat skor 4(sangat baik). Pada siklus kedua kedua puluh guru tersebut mencantumkan tujuan pembelajaran dalam RPP-nya. Lima orang mendapat skor 7 (baik) dan dua puluh orang mendapat skor 4 (sangat baik). Jika dipersentasekan, 93\%, terjadi peningkatan 38\% dari siklus I.

6. Komponen Materi Ajar

Pada siklus pertama semua guru (dua puluh orang) mencantumkan materi ajar dalam RPP-nya (melengkapi RPP-nya dengan materi ajar). Jika dipersentasekan, 62\%. satu orang guru masing-masing mendapat skor 1 (kurang baik) dan tiga orang mendapat skor 2 (cukup baik), lima orang mendapat skor 3 (baik). lima orang guru masing-masing mendapat skor 4 (sangat baik), dan Pada siklus kedua kedua puluh guru tersebut mencantumkan materi ajar dalam RPP-nya. sepuluh orang guru mendapat skor 3 (baik) dan empat orang guru mendapat skor 4 (sangat baik). Jika dipersentasekan, 89\%, terjadi peningkatan $27 \%$ dari siklus I.

7. Komponen Alokasi Waktu

Pada siklus pertama semua guru (dua puluh orang) mencantumkan alokasi waktu dalam RPP-nya (melengkapi RPP-nya dengan alokasi waktu). Semuanya mendapat skor 4 (sangat baik). Jika dipersentasekan, 100\%. Pada siklus kedua kedua puluh guru tersebut mencantumkan alokasi waktu dalam RPP-nya. Semuanya mendapat skor 4 (sangat baik). Jika dipersentasekan, 100\%.

8. Komponen Metode Pembelajaran

Pada siklus pertama semua guru (dua puluh orang guru) mencantumkan metode pembelajaran dalam RPP-nya (melengkapi RPP-nya dengan metode pembelajaran). Jika dipersentasekan, 52\%. enam orang 
guru mendapat skor 2 (cukup baik), empat orang mendapat skor 3 (baik), dan empat orang mendapat skor 4 (sangat baik). Pada siklus kedua kedua puluh guru tersebut mencantumkan metode pembelajaran dalam RPP-nya. Satu orang mendapat skor 2 (cukup baik), sembilan orang mendapat skor 3 (baik), dan empat orang mendapat skor 4 (sangat baik). Jika dipersentasekan, 93\%, terjadi peningkatan 41\% dari siklus I.

9. Komponen Langkah-Langkah Kegiatan Pembelajaran

Pada siklus pertama semua guru (dua puluh orang) mencantumkan langkah-langkah kegiatan pembelajaran dalam RPP-nya (melengkapi RPP-nya dengan langkah-langkah kegiatan pembelajaran). Jika dipersentasekan, 52\%. Empat orang guru mendapat skor 2 (cukup baik), sedangkan tujuh orang mendapat skor 3 (baik), tiga orang guru mendapat skor 4(sangat baik). Pada siklus kedua kedua puluh guru tersebut mencantumkan langkah-langkah kegiatan pembelajaran dalam RPP-nya. satu orang mendapat skor 2 (cukup baik) dan delapan belas orang mendapat skor 3 (baik). lima orang guru mendapat skor 4(sangat baik). Jika dipersentasekan, 89\%, terjadi peningkatan 37\% dari siklus I.

10. Komponen Sumber Belajar

Pada siklus pertama semua guru (dua puluh orang) mencantumkan sumber belajar dalam RPP-nya (melengkapi RPP-nya dengan sumber belajar). Jika dipersentasekan, 66\%. Dua orang guru mendapat skor 2 (cukup baik), delapan orang mendapat skor 3 (baik), empat orang guru mendapat skor 4 (sangat baik). Pada siklus kedua kedua puluh guru tersebut mencantumkan sumber belajar dalam RPP-nya. Dua orang mendapat skor 2 (cukup baik) dan enam mendapat skor 3 (baik), 6 orang guru mendapat skor 4(sangat baik). Jika dipersentasekan, $93 \%$, terjadi peningkatan $27 \%$ dari siklus I.

\section{Komponen Penilaian Hasil Belajar}

Pada siklus pertama semua guru (dua puluh orang) mencantumkan penilaian hasil belajar dalam RPP-nya meskipun sub-sub komponennya (teknik, bentuk instrumen, soal), pedoman penskoran, dan kunci jawabannya kurang lengkap. Jika dipersentasekan, $45 \%$. tiga orang guru masing-masing mendapat skor 1 dan tiga guru masing-masing mendapat skor 2 (cukup baik), lima orang mendapat skor 3 (baik), dan tiga orang mendapat skor 4 (sangat baik). Pada siklus kedua kedua puluh guru tersebut mencantumkan penilaian hasil belajar dalam RPP-nya meskipun ada guru yang masih keliru dalam menentukan teknik dan bentuk penilaiannya. Tiga orang mendapat skor 2(cukup baik), Tujuh orang mendapat skor 3 (baik) dan empat orang mendapat skor 4 (sangat baik). Jika dipersentasekan, $55 \%$, terjadi peningkatan $10 \%$ dari siklus I.

Berdasarkan pembahasan di atas terjadi peningkatan kompetensi guru dalam menyusun RPP. Pada siklus I nilai rata-rata komponen RPP $71 \%$, pada siklus II nilai rata-rata komponen RPP 91\%, terjadi peningkatan $20 \%$.

\section{Simpulan}

Berdasarkan hasil Penelitian Tinadakan Sekolah (PTS) dapat disimpulkan sebagai berikut.

1. Work shop dan bimbingan berkelanjutan dapat meningkatkan motivasi guru dalam menyusun RPP dengan lengkap. Guru menunjukkan keseriusan dalam memahami dan menyusun RPP apalagi setelah melaksanakan work shop mendapatkan bimbingan pengembangan/penyusunan RPP dari peneliti. Informasi ini peneliti peroleh dari hasil pengamatan pada saat mengadakan wawancara dan bimbingan pengembangan/penyusunan RPP kepada para guru.

2. Bimbingan berkelanjutan dapat meningkatkan kompetensi guru dalam menyusun RPP. Hal itu dapat dibuktikan dari hasil observasi /pengamatan yang memperlihatkan bahwa terjadi peningkatan kompetensi guru dalam menyusun RPP dari siklus ke siklus . Pada siklus I nilai rata-rata komponen RPP $71 \%$ dan pada siklus II $91 \%$. Jadi, terjadi peningkatan $20 \%$ dari siklus I.

\section{Referensi}

BSNP. (2007). Peraturan Menteri Pendidikan Nasional Republik Indonesia Nomor 16 Tahun 2007 Tentang Standar Kualifikasi Akademik dan Kompetensi Guru. Jakarta : BSNP.

Peraturan Menteri Pendidikan Nasional Republik Indonesia Nomor 41 Tahun 2007 Tentang Standar Proses untuk Satuan Pendidikan Dasar dan Menengah.

Peraturan Pemerintah Nomor 19 Tahun 2005 tentang Standar Nasional Pendidikan. 
Undang-Undang Republik Indonesia Nomor 14 Tahun 2005 tentang Guru dan Dosen.

Undang-Undang Republik Indonesia Nomor 20 Tahun 2003 Tentang Sistem Pendidikan Nasional.

Depdiknas. (2008). Pedoman Penelitian Tindakan Sekolah (School Action Research) Peningkatan Kompetensi Supervisi Pengawas Sekolah SMA / SMK. Jakarta : Dirjen PMPTK.

Panitia Pelaksana Pendidikan dan Latihan Profesi Guru Rayon 10 Jawa Barat. (2009). Bahan Ajar Pendidikan dan Latihan Profesi Guru (PLPG), Pengawas. Bandung : Universitas Pendidikan Indonesia.

Asrori,Muhammad. (2008). Penelitian Tindakan Kelas. CV. Wahana Prima, Bandung Terbuka.

Mulyasa, E. (2003). Kurikulum Berbasis Kompetensi: Konsep, Karakteristik, dan Implementasi. Bandung: PT Remaja Rosdakarya

Sudjana, H. Nana. (2009). Penelitian Tindakan Kepengawasan, Konsep dan Aplikasinya bagi Pengawas Sekolah. Jakarta : Binamitra Publishing. 